\section{U.S.S.R. Fisheries Research by Submarine}

VALUABLE oceanographic and fisheries work has been accomplished by a specially constructed submarine, Severyanka, as described by V. P. Zaitzev (Priroda, 8, 71; 1959). The submarine is provided with a viewing apparatus, several projectors, mechanical arms for collecting specimens from the bottom of the sea, echo-sounding apparatus and a cinema apparatus. The first sailing in the Barents Sea took place on December 14, 1958. Nine scientists were aboard. The second expedition took place during December 29, 1958-January 21, 1959, in the northern part of the Atlantic Ocean, and which covered some 4,000 nautical miles, aimed at the study of herring movements.

\section{National Science Foundation Awards for Graduate Research Facilities}

The U.S. National Science Foundation has awarded grants totalling $2,153,710$ dollars to fifty-four colleges and universities to improve graduate research laboratories. These grants are made on condition that the institution concerned provides at least 50 per cent of the funds needed. This permits assistance to a larger number of financially hard-pressed institutions and at the same time stimulates self-help to the greatest extent possible by the institution. Grants provide for construction, conversion or modernization of laboratory facilities.

\section{The Institute of Metals : Annual Autumn Meeting}

THE fifty-second annual autumn meeting of the Institute of Metals will take place at Bath during September 5-9. The meeting will be held partly at the Pump Room and partly at Guildhall. Included in the programme are such topics as: "Engineering Properties of Nickel-Base Alloys" and "Lubricants for Cold Rolling Aluminium" (September 5) ; "Recovery and Recrystallization" and "Engineering Properties of Alloys" (September 6) ; "The Relative Merits of Extrusion and Other Methods for the Manufacture of Bar, Rod and Wire-Rod" and "Magnesium Alloys for Fuel--Element Components" (September 8). The Autumn Lecture, on "Metals and the World of Engineering Structures", will be given by Sir Alfred Pugsley on September 9. Further information can be obtained from the Secretary, Institute of Metals, 17 Belgrave Square, London, S.W.1.

\section{Announcements}

DURING the past few years, many entomologists have inquired for insect suction traps which segregate the catch by dropping disks into the collecting tube. One firm may now agree to make the 9 -in. Vent-Axia type (as described in Annals of Applied Biology, 37, $80 ; 38,582$ ) for approximately $£ 100$ each, complete with time switch, provided fifty orders are placed. Will those interested please communicate with Dr. C. G. Johnson, Rothamsted Experimental Station, Harpenden.

A Stemring Committee, originally appointed as a working party by the Faraday Society to consider the future of its work in the field of biophysics, has decided to launch a new and independent society to be known as the British Biophysical Society. The chairman and secretary of the Steering Committee are Prof. J. A. V. Butler and Dr. J. C. Kendrew respectively. The first scientific meeting of the new Society will take place in London in December. A more detailed announcement, giving information about the new Society and about its first meeting, and inviting inquiries from prospective members, will be made shortly.

Supplements 9 and 10 to the Index-Catalogue of Medical and Veterinary Zoology issued by the United States Department of Agriculture, June 1959 and April 1960, respectively, covering authors from A to $\mathrm{Z}$, are now available (Supplement 9. Pp. $1+322$. 1.25 dollars. Supplement $10 . \quad$ Pp. $\mathrm{i}+357$. 1.25 dollars. Washington, D.C. : Government Printing Office, 1959 and 1960).

THE fifth annual conference of the British Society for the Philosophy of Science will be held at Wills Hall, Bristol, during September 23-25. Further information can be obtained from Dr. M. B. Hesse, Whipple Museum, Free School Lane, Cambridge.

An International Congress on Experimental Mechanies will be held during November 1-3, 1961, in New York City. Further information can be obtained from Dr. Roscoe Guernsey, jun., General Engineering Laboratory, General Electric Company, Schenectady 5 , New York.

ThE twenty-first National Conference for the Preservation of the Countryside will be held at Weymouth during October 13-15. Further information can be obtained from the General Secretary, The Council for the Preservation of Rural England, 4 Hobart Place, London, S.W.I.

THE Metallurgy Society of France is organizing a meeting on "The Heat Treatment of Metals and Alloys" during October 17-21. The meeting will be held at la Maison de la Chimie, 28 bis, rue SaintDominique, Paris 7e. Further information can be obtained from the Secretary-General of the Society, 25 Rue de Clichy, Paris $9 \mathrm{e}$.

THE tenth annual Instrument Symposium and Research Equipment Exhibit are to be held at the National Institutes of Health, Washington, D.C., during October 3-6 and October 4-7, respectively. Further information can be obtained from V. B. Davis, National Institutes of Health, Public Health Service, Bethesda 14, Maryland.

THE second International Plastics Exhibition will be held in Utrecht during October 19-26. Immediately preceding the Exhibition, an international congress on "The Technology of Plastics Processing" will be held in Amsterdam during October 17-19. The congress is sponsored by the Association for the Advancement of the Knowledge of Materials, the Royal Institute of Engineers, the Royal Netherlands Chemical Federation and the International Union of Pure and Applied Chemistry. Further information can be obtained from N. V. 't Raedthuys, Terselschadestraat 5, Amsterdam.

Erratum. In the communication entitled "Synergetic Action of 2(o-Methoxyphenoxymethyl)-5Oxazolidone on Morphine, Dihydrocodeine and Aminopyrine Analgesia,", by E. Fischer, J. L. J. Szabó and M. Stamburgo, in Nature of June 11, p. 893, the authors state that they gave the chemical name of metoxadone incorrectly; it should read 5 (o-methoxyphenoxymethyl)-2-oxazolidone in both title and first line of text. 